Article

\title{
Ochratoxin A: In Utero Exposure in Mice Induces Adducts in Testicular DNA
}

Jamie E. Jennings-Gee ${ }^{1}$, Mariana Tozlovanu ${ }^{2}$, Richard Manderville ${ }^{3}$, Mark Steven Miller ${ }^{1}$, Annie Pfohl-Leszkowicz ${ }^{2, *}$ and Gary G. Schwartz ${ }^{1,4, *}$

1 Department of Cancer Biology, Wake Forest University, Winston-Salem, North Carolina, USA; E-Mails: jjenning@wfubmc.edu (J.E.J-G.); msmiller@wfubmc.edu (M.S.M.)

2 Laboratory Chemical engineering, Department Bioprocess \& Microbial System, UMR CNRS/INPT/UPS 5503, ENSA Toulouse, France; E-Mail: mariana.tozlovanu@ensat.fr (M.T.) Department of Chemistry, University of Guelph, Guelph Ontario, Canada;

E-Mail: rmanderv@uoguelph.ca (R.M.)

4 Department of Cancer Biology, Urology, and Epidemiology and Prevention, Wake Forest University, Winston-Salem, North Carolina, USA

* Authors to whom correspondence should be addressed; E-Mails: leszkowicz@ensat.fr (A.P.-L.); gschwart@wfubmc.edu (G.G.S.); Tel.: + 33-5-34323947 (A.P.-L.); +1-336-716-7446 (G.G.S.); Fax: + 33-5-34323947(A.P.-L.); +1-336-716-5687 (G.G.S.).

Received: 15 April 2010; in revised form: 26 May 2010 / Accepted: 8 June 2010 /

Published: 11 June 2010

Abstract: Ochratoxin A (OTA) is a nephrotoxin and carcinogen that is associated with Balkan endemic nephropathy and urinary tract tumors. OTA crosses the placenta and causes adducts in the liver and kidney DNA of newborns. Because the testis and kidney develop from the same embryonic tissue, we reasoned that OTA also may cause adducts transplacentally in the testis. We tested the hypothesis that acute exposure to OTA, via food and via exposure in utero, causes adducts in testicular DNA and that these lesions are identical to those that can be produced in the kidney and testis by the consumption of OTA. Adult mice received a single dose of OTA (from $0-1,056 \mu \mathrm{g} / \mathrm{kg}$ ) by gavage. Pregnant mice received a single i.p. injection of OTA $(2.5 \mathrm{mg} / \mathrm{kg})$ at gestation day 17 . DNA adducts were determined by ${ }^{32} \mathrm{P}$-postlabeling. Gavage-fed animals sacrificed after 48 hours accumulated OTA in kidney and testis and showed DNA adducts in kidney and testis. Some OTA metabolites isolated from the tissues were similar in both organs (kidney and testis). The litters of mice exposed prenatally to OTA showed no signs of overt toxicity. However, 
newborn and 1-month old males had DNA adducts in kidney and testis that were chromatographically similar to DNA adducts observed in the kidney and testis of gavage-fed adults. One adduct was identified previously as C8-dG-OTA adduct by LC MS/MS. No adducts were observed in males from dams not exposed to OTA. Our findings that in utero exposure to OTA causes adducts in the testicular DNA of male offspring support a possible role for OTA in testicular cancer.

Keywords: ochratoxin; testicular cancer; DNA adduct; transplacental contamination; epidemiology

\section{Introduction}

Ochratoxin A (OTA) is a mycotoxin produced by species of Aspergillus and Penicillium that has long been studied as a nephrotoxin, immunotoxin, teratogen and carcinogen (for recent reviews see [1-3]). OTA contamination of grain is the cause of mycotoxic porcine nephropathy (a.k.a., "Danish nephropathy"), a renal disease of swine that is an important cause of economic losses in the pork industry [4,5] and may be responsible for some cases of nephropathy and cancer in humans [2]. Specifically, OTA is strongly implicated as the cause of Balkan endemic nephropathy (BEN), a fatal tubulointerstitial disease that is associated with renal atrophy $[2,6,7]$ and that exhibits features similar to porcine nephropathy in Bulgaria [5,7]. Approximately 30\% of patients dying with BEN have tumors of the urinary tract $[6,8]$. High amounts of OTA are found in human sera in regions where OTA contamination of food stuffs is high, particularly northern Europe (for reviews see [2,7]).

Several areas of the Balkans that are known to have high levels of OTA-contamination of food have recently experienced a marked increase in the incidence of testicular cancer. For example, from 1960 to 1985, the incidence of testicular cancer in Vas, Hungary, increased 5-fold, from 1.2 to 6.1/100,000 [9]. A similar increase was reported for Slovenia [9]. A possible etiologic role for OTA in testicular cancer in men was hypothesized in 2002 by Schwartz [10], who noted that the unusual geographic distribution of testis cancer, with especially high rates in Denmark, was correlated with the national per capita consumption of OTA-contaminated foods. Recent toxicologic data in rodents support the concept that dietary exposure to OTA can influence carcinogenesis in the testis. For example, Ueta et al., [11] administered $2 \mathrm{mg} / \mathrm{kg}$ OTA intraperitoneally to Pdn/Pdn mice on day 7.5 of gestation. They observed a significant depression of Dmrt-I gene expression in the male conceptuses on day 9 [11]. Dmrt-1 (also known as doublesex and mab-3 related transcription factor 1 ) is essential for the normal development of the mammalian testis [12]. More direct evidence of a carcinogenic role for OTA in the testis was provided by Mantle and Nolan [13]. These investigators administered $100 \mu \mathrm{g}$ OTA as a daily dietary contaminant to 24 male Fischer rats for 35 weeks. Testis tumors developed in six of the rats (25\%), an incidence rate equal to that of renal tumors in male Fischer rats chronically exposed to dietary OTA [14].

In adult rodents, OTA consumption causes adducts in liver, kidney and testicular DNA [15,16]. OTA also crosses the placenta and causes adducts in the liver and kidney DNA of newborns $[17,18]$. Because the testis and kidney develop from the same embryonic tissue, the mesonephros [19,20], we reasoned that OTA also may cause adducts transplacentally in the testis. We hypothesized that 
exposure to OTA during early life, either via consumption of foods that are contaminated with OTA or via exposure to OTA in utero, can cause lesions in testicular DNA. This research tests the hypothesis that in utero exposure to OTA causes adducts in testicular DNA and that these lesions are similar to those that can be produced in the kidney and testis by the consumption of OTA.

In addition, we showed previously that OTA forms a benzoquinone electrophile following activation by cytochrome P450 enzymes and radical species following activation of enzymes with peroxidase activities. These electrophiles react preferentially with deoxy guanine to form benzethenoadduct and C8 dG-OTA. Analysis of OTA-mediated DNA adduct by ${ }^{32} \mathrm{P}$ post labelling method correlates with OTA chemistry and adduct spots derived from quinone electrophiles which are generated following activation by cytochrome P 450, while a C-8 dG OTA adduct is formed following activation of OTA by peroxidises, mainly contained in kidney and testis (for a review see [21]). In this study we further characterized the OTA metabolites in tissues from adult animals exposed to OTA.

\section{Experimental Section}

\subsection{Chemicals}

OTA (benzene free), 3'-dGMP, Proteinase K, RNase A, RNase T1 (boiled for 10 min at $100{ }^{\circ} \mathrm{C}$ to destroy DNases), and microccocal nuclease (dialyzed against deionized water) were purchased from Sigma-Aldrich (Saint-Quentin Fallavier, France); spleen phosphodiesterase (centrifuged before use) from Calbiochem (VWR, France); and nuclease P1 and T4 polynucleotide kinase from Roche (Meylan, France). [ $\left.\gamma^{32} \mathrm{P}-\mathrm{ATP}\right](444 \mathrm{Tbq} / \mathrm{mmol}, 6000 \mathrm{Ci} / \mathrm{mmol})$ was obtained from Amersham (Les Ullis, France); rotiphenol ( $\mathrm{pH}$ 8) from Rothsichel (Lauterbourg, France); cellulose MN 301 from Macherey Nagel (Düren, Germany); polyethyleneimine (PEI) from Corcat (Virginia Chemicals, Portsmouth, VA); and Whatman No. 1 paper from VWR (France). Authentic 3'dGMP-OTA standard was prepared chemically prepared at Guelph University as described in detail [22]. All reagents, excluding solvents were of normal purity. Solvents were HPLC grade from ICS (Lapeyrouse-Fossat, France). Deionized water from a Milli-Q system (Millipore, France) was used for the preparation of all aqueous solutions for HPLC analysis.

4-S-OH-OTA, 4-R-OHOTA, and 10 hydroxylated OTA (10-OH-OTA) were a gift from Dr Størmer. Quinone OTA (OTHQ) was prepared as described in Gillman et al., 1999 [23]. Glutathione (GSH) metabolites such OTHQ-GSH and OTA-GSH were formed in vitro by autooxidation as follows: $10 \mu \mathrm{M}$ of either OTHQ or OTA dissolved in phosphate buffer (100 mM, pH 7.4) were incubated for $45 \mathrm{~min}$ at $37^{\circ} \mathrm{C}$ in presence of $1 \mathrm{mM}$ GSH. N-acetylcystein (NAC) metabolites such OTHQ-NAC and OTA-NAC were formed in vitro by autooxidation as follows: $10 \mu \mathrm{M}$ of either OTHQ or OTA dissolved in phosphate buffer (100 mM, pH 7.4) were incubated for $45 \mathrm{~min}$ at $37^{\circ} \mathrm{C}$ in presence of $1 \mathrm{mM}$ NAC.

\subsection{Animals and Treatment}

\subsubsection{Acute Gavage Feeding Studies}

Seven week-old male BALB/c mice, weighing 20g \pm 2 , were purchased from IFFA-CREDO, L'Arbresle, France and were housed in individual cages and kept in environmentally controlled 
conditions (ventilation, $22{ }^{\circ} \mathrm{C}, 12$ hours dark/light cycles). After an acclimation period of one week, 3 mice per group were given OTA dissolved in olive oil by a single intragastric intubation (oral gavage, 3.5; 7; 35; 70; 289; 578; $1056 \mu \mathrm{g} / \mathrm{kg} / \mathrm{b} . w$.$) . The control group of four mice received only olive$ oil. Mice were sacrificed $48 \mathrm{~h}$ after OTA administration. Testis and kidney were frozen immediately on dry ice and stored at $-80^{\circ} \mathrm{C}$ pending analysis of OTA content, OTA metabolites content and DNA adducts.

\subsubsection{Subchronic Feeding Studies}

Seven week-old male BALB/c mice, weighing $20 \mathrm{~g} \pm 2$, purchased from IFFA-CREDO, L'Arbresle, France were housed in individual cages and were kept under the same conditions as mice fed OTA by gavage. After an acclimation period of one week, 5 mice per group were given feed containing increasing amount of OTA $(0.5,1.4 ; 8 ; 20 \mu \mathrm{g} / \mathrm{kg} / \mathrm{b} . w$.$) every day during 4$ weeks. The feed (global rodent diets) was provided by Harlan Laboratory, Lyon, France. The feed was tested for the presence of mycotoxins after purification by partition for OTA, citrinin and aflatoxins and purification on IAC (Libios, France) for fumonisin B1 and zearalenone. The detection of the mycotoxins was performed by separation on HPLC with fluorimetric detection as described by Molinié et al., 2005 [24] and by Nguyen et al., 2007 [25]). None of these mycotoxins were detected. Feed was experimentally contaminated with OTA by mixing it with a solution of OTA to reach the desired concentrations. Five animals received feed without OTA as control.

\subsubsection{Transplacental Studies}

Six to 8 weeks old inbred Swiss (SWR/J) mice were purchased from The Jackson Laboratory (Bar Harbor, ME, USA). We first performed studies to determine the potential toxicity of OTA delivered i.p. to Swiss mouse dams at day 17 of gestation. Dams were monitored for signs of overt toxicity. Potential toxicity to offspring was measured by determination of number of pups born, average litter weight, survival to weaning and weight at 1 month.

Animals were housed in plastic cages with hardwood shaving bedding. They were maintained on a 12 hours dark/light cycle and were allowed free access to food and water. After acclimation for two weeks, mice were mated by placing 2 to 3 females in a cage with one male. Pregnant mothers were treated on the 17th day of pregnancy (day one of pregnancy was the first day following overnight mating) by a high i.p. injection with either $2.5 \mathrm{mg} / \mathrm{kg} / \mathrm{b} . \mathrm{w}$. OTA dissolved in olive oil or olive oil alone (control) at an equivalent volume.

For adduct analysis, pups were sacrificed at birth, their gender was identified at necropsy, and kidneys and testes were removed from the males. Newborn testes and kidneys were frozen immediately following the same protocol as for the gavage-fed mice. Additionally, male mice from 4 litters (two OTA-treated, two controls) were maintained for one month and then sacrificed. Kidney and testicular tissues were removed, frozen, and used for quantitation of DNA adducts. 


\subsection{OTA and OTA Metabolites Determination in Tissues}

\subsubsection{Analysis of OTA Content in Tissues of Adult Mice}

Tissue OTA content was extracted and measured as described by Petkova-Bocharova et al., 2003 [26]. Briefly, $500 \mathrm{mg}$ of tissue was homogenized with $10 \mathrm{~mL}$ of $0.1 \mathrm{M} \mathrm{MgCl}_{2} / 0.05 \mathrm{M} \mathrm{HCl}, \mathrm{pH} 1.5$ and extracted three times with chloroform. Combined chloroform extracts were extracted twice against sodium hydrogen carbonate, the aqueous phase acidified to $\mathrm{pH} 1.5$, and further extracted with chloroform. Combined chloroform extracts were dried under vacuum, dissolved in methanol, filtered, dried under nitrogen and dissolved in $200 \mu \mathrm{L}$ of methanol for HPLC analysis. OTA was analysed by reverse phase HPLC using a Nucleosil 100-3-C18 column, $15 \mathrm{~cm}$ under isocratic elution (Methanol, $600 \mathrm{~mL}$; acetonitrile, $600 \mathrm{~mL}$; ultrapure water, $800 \mathrm{~mL}$; sodium acetate, $3 \mathrm{H}_{2} \mathrm{O}, 0.68$ g; glacial acetic acid, $28 \mathrm{~mL}$ ) run 30 minutes. Detection was performed with a programmable fluorimeter GTI spectrovision (excitation $340 \mathrm{~nm}$, emission, $465 \mathrm{~nm}$ ). HPLC grade solvent columns were supplied by ICS (Lapeyrouse-Fossat, France). The limit of detection (LOD) was $0.05 \mathrm{ng} / \mathrm{g}$; the limit of quantification (LOQ) $0.2 \mathrm{ng} / \mathrm{g}$.

\subsubsection{Analysis of OTA Metabolites in Tissues of Adult Mice}

The metabolites were separated on prontosil $250 \mathrm{~mm} \times 4 \mathrm{~mm}, 3 \mu$ using the following gradient: solvent A: MeOH/ACN/6.5 mM ammonium formate (200/200/600) adjusted to pH 3 with formic acid; solvent B: MeOH/ACN/6.5 mM ammonium formate (350/350/300) adjusted to $\mathrm{pH} 3$ with formic acid. Program: T0 min 100\% A; T10 min 100\% A; T25 min 30\% A; T30 min 30\% A; T45 min 0\% A; T55 min 0\% A; T58 min as described in Faucet-Marquis et al., 2006 [27]. Detection was performed with a programmable fluorimeter GTI spectrovision (ex $=350$ and em $=510 \mathrm{~nm}$ ), allowing better detection of some OTA metabolites [28].

\subsection{DNA Adduct Detection and Identification of C-C8dG OTA Adduct}

Kidney and testis DNA isolation and purification as well as the method used for ${ }^{32} \mathrm{P}$-postlabeling were performed as described by Faucet et al., [22] and in detail by Pfohl-Leszkowicz \& Castegnaro [29]. In brief, the equivalent of $7 \mu \mathrm{g}$ of DNA was dried in vacuo, dissolved in $10 \mu \mathrm{L}$ of the mix containing $1 \mu \mathrm{L}$ of micrococcal nuclease ( $2 \mathrm{mg} / \mathrm{mL}$ corresponding to $500 \mathrm{U}$ ), spleen phosphodiesterase

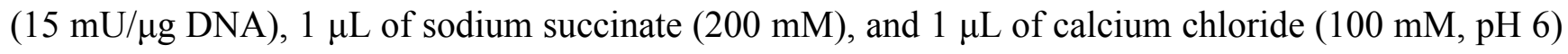
and digested at $37{ }^{\circ} \mathrm{C}$ for $4 \mathrm{~h}$. The digested DNA was then treated with $5 \mu \mathrm{L}$ of the mix containing $1.5 \mu \mathrm{L}$ of nuclease P1 $(4 \mathrm{mg} / \mathrm{mL}), 1.6 \mu \mathrm{L}$ of $\mathrm{ZnCl}_{2}(1 \mathrm{mM})$, and $1.6 \mu \mathrm{L}$ of sodium acetate $(0.5 \mathrm{M}$, $\mathrm{pH}$ ) at $37^{\circ} \mathrm{C}$ for $45 \mathrm{~min}$. The reaction was stopped by the addition of $3 \mu \mathrm{L}$ of Tris base $500 \mathrm{mM}$. The DNA adducts were labeled as follows: to the nuclease P1 digest, $5 \mu \mathrm{L}$ of the reaction mixture containing $2 \mu \mathrm{L}$ of bicine buffer [bicine $(800 \mu \mathrm{M})$, dithiothreitol $(400 \mathrm{mM}), \mathrm{MgCl}_{2}(400 \mathrm{mM})$, and spermidine (400 mM) adjusted to $\mathrm{pH} 9.8$ with $\mathrm{NaOH}$ ], $10 \mathrm{U}$ of polynucleotide kinase $\mathrm{T} 4$, and $100 \mu \mathrm{Ci}$ of $\left[\gamma_{-}{ }^{32} \mathrm{P}\right] \mathrm{ATP}$ (specific activity $6000 \mathrm{Ci} / \mathrm{mmol}$ ) was added and the mixture incubated at $37{ }^{\circ} \mathrm{C}$ for 45 min. Normal nucleotides, pyrophosphate, and excess ATP were removed by chromatography on $\mathrm{PEI} /$ cellulose TLC plates (D1) in $2.3 \mathrm{M} \mathrm{NaH}_{2} \mathrm{PO}_{4}$ buffer, $\mathrm{pH}$ 5.7, overnight. The original $(2 \mathrm{~cm})$ areas 
containing labeled adducted nucleotides were cut out and transferred to another PEI/cellulose TLC plate, which was run (D2) in 4.8 $\mathrm{M}$ lithium formate and 7.7 $\mathrm{M}$ urea, $\mathrm{pH}$ 3.5, for $3 \mathrm{~h}$. A further (D3) migration was performed after turning the plate $90^{\circ}$ anticlockwise in $0.6 \mathrm{M} \mathrm{NaH2PO} 4$ and $5.95 \mathrm{M}$

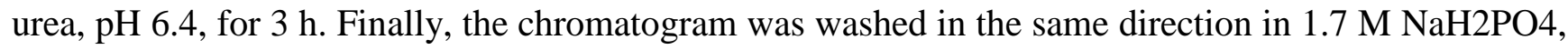
$\mathrm{pH}$ 6, for $2 \mathrm{~h}$ (D4). Adduct profiles were analyzed qualitatively and semi-quantitatively by autoradiography of the plates, carried out at $-80{ }^{\circ} \mathrm{C}$ for $48 \mathrm{~h}$ in the presence of an intensifying screen using a radioanalytical system of image analysis (AMBIS, Lablogic).

Identification of one DNA adduct was made by comigration with authentic standard. The standard OTA-3'P-dGMP adduct (C-C8) was dissolved in sterile deionised water. A dilution corresponding to 143 fmol of adducts was ${ }^{32} \mathrm{P}$-postlabeled. OTA adduct in testis DNA was identified by either co-chromatography of DNA adducts from the testis (3.5 $\mu$ g of digested DNA) and OTA standard or with DNA adducts from kidneys (3.5 $\mu \mathrm{g}$ of digested DNA in the conditions used for purified DNA). Isolation of this specific adduct was performed following the technique developed by Mantle et al., 2010 [30]. In brief, the cellulose in the central area corresponding to spots of interest was scraped off. The cellulose was suspended in methanol, shaken and centrifuged; the solution and the extraction cycle was repeated. Residual cellulose was then similarly extracted with triethanolamine. Combined extracts were evaporated to dryness in vacuum. The residue was solved in methanol and put on PEI cellulose for additional D2, D3, D4.

\section{Results}

\subsection{Acute and Subchronic Effect of OTA on Adult Male Mice}

Three animals per group received a single dose of OTA and were sacrificed $48 \mathrm{~h}$ after treatment. Three control animals received only vehicle. The control animals also were sacrificed $48 \mathrm{~h}$ later. For the subchronic study, five animals per group were fed OTA (in feed). DNA was extracted from kidney and testis. OTA and its derivatives were extracted and analyzed by HPLC.

\subsubsection{DNA Adduct Detection}

DNA adducts were analyzed in kidney and testes of male mice treated either acutely or subchronically by increasing amount of OTA using the postlabeling technique after nuclease P1 enrichment. This technique allows detection of covalent DNA adducts only. No DNA adducts were observed either in kidney and testis of mice receiving only vehicle. Several individual DNA adducts are observed in kidney and testis after exposure over $7 \mu \mathrm{g} / \mathrm{kg}$ b.w. An example of DNA adduct patterns is shown in Figure 1.

The numbers of individual adducts and the intensity of the DNA adducts increased with the exposure. A low exposure led mainly to the formation of the DNA adducts 1 and 2. High acute exposure induced at least 7 different DNA adducts (Figure $2 \mathrm{~A}$ ). The DNA adducts formed in testis are similar to those formed in kidney (Figures 1C \& D). DNA adduct 1 corresponding to C-C8dG OTA (see below 3.2.2 and Faucet et al., 2004 [22]; Mantle et al., 2010 [30]) is the main adduct in both organs. This adduct is also formed even after chronic exposure as low as $0.5 \mu \mathrm{g} / \mathrm{kg} \mathrm{b} . \mathrm{w}$, and increased 
with dose (Figure 2B). Although adduct 6 is formed in both organs, it is formed to larger extent in kidney after acute exposure. After chronic exposure, adducts 2, 3 and 7 are also formed in testis.

Figure 1. DNA adduct pattern in tissues of mice treated with Ochratoxin A. (A) kidney DNA from control mice; (B) testis DNA from control mice; (C) kidney DNA adduct from mice treated with $1056 \mathrm{mg} / \mathrm{kg}$ b.w.; (D) testis DNA adduct from mice treated with $1,056 \mathrm{mg} / \mathrm{kg}$ b.w.; (E) Scheme of numbering of the individual DNA adducts. Exposure time of the film was $48 \mathrm{~h}$.
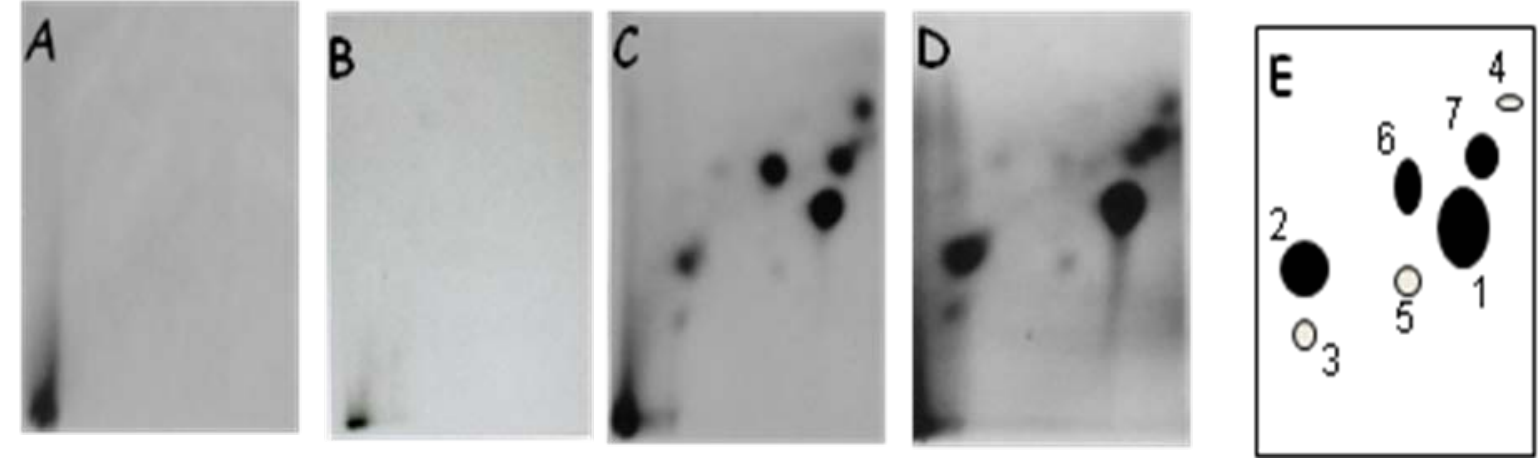

Figure 2. DNA adduct pattern in testis of male mice exposed to ochratoxin A. (A) acute exposure (gavage); (B) mice were fed 4 weeks with feed containing OTA. Doses are expressed as $\mu \mathrm{g} / \mathrm{kg}$ b.w. The films were exposed for $24 \mathrm{~h}$ panel (A) and $48 \mathrm{~h}$ panel (B).
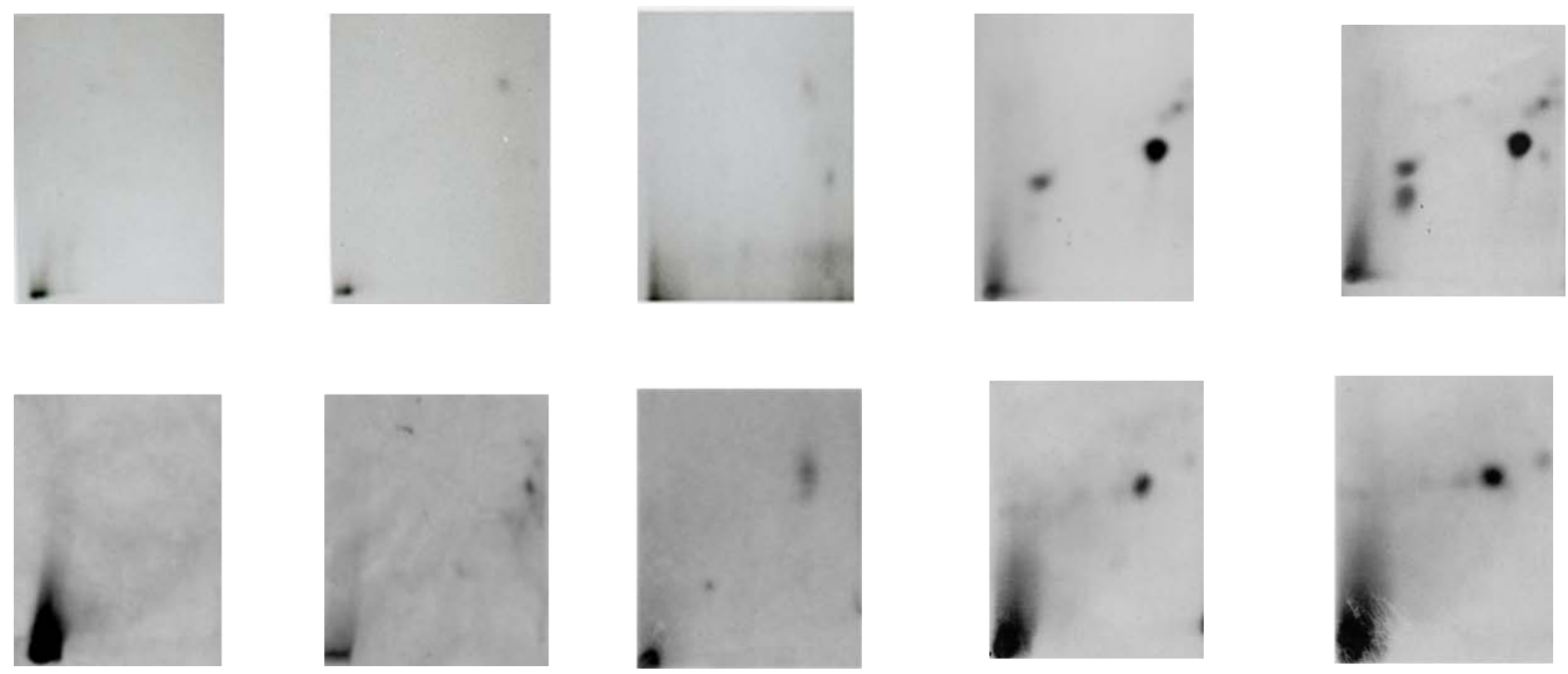

The amounts of C-C8dG OTA observed in kidney and testis of mice exposed by gavage are given in Figure 3. The amount of C-C8 dG-OTA adduct (spot labeled number 1 in the scheme Figure 1) formed in kidney and testis are in the same range for dose treatment below $1056 \mu \mathrm{g} / \mathrm{kg} \mathrm{b} . \mathrm{w}$. In the case of high exposure, the amount of C-C8dG OTA was 25\% higher in testis than in kidney. 
Figure 3. Amount of C-C8dG OTA, expressed as relative adduct level, in organs of mice exposed to increasing amount of ochratoxin A (single dose). Amount in testis = hatched bar; amount in kidney = white bar.

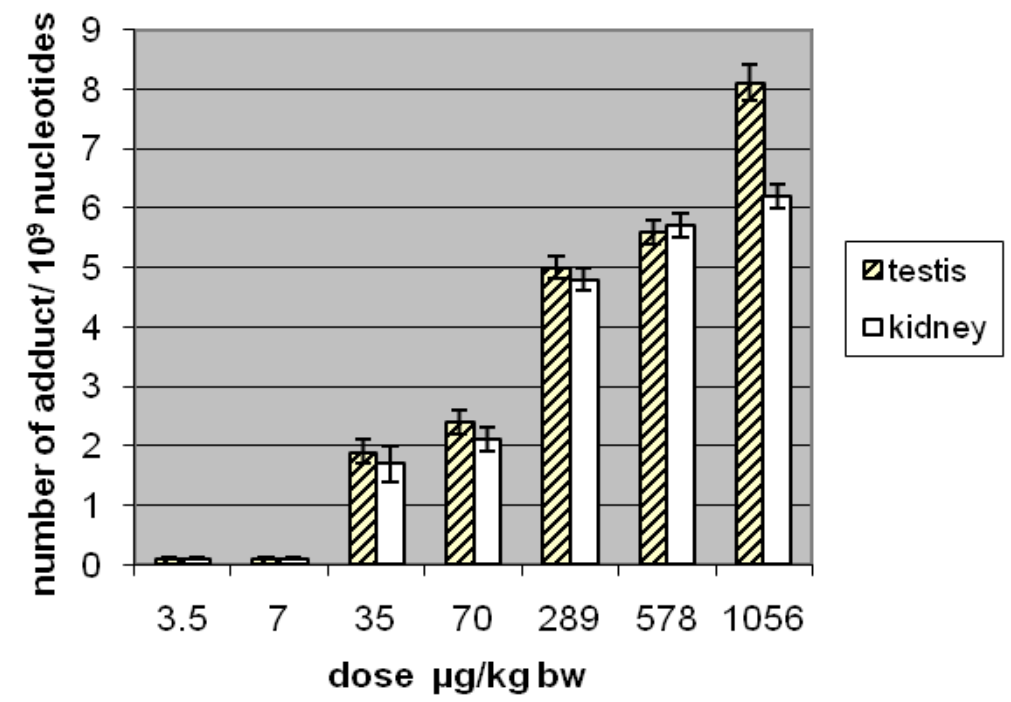

\subsubsection{Amount of OTA in Kidney and Testis of Adult Mice}

Table 1 summarizes the OTA content in testis and kidney from BALB/c mice, administered increasing doses of OTA by a single gavage. The data show that the quantity of OTA stored in tissues increased with the dose administered, but the increase was not linear. The kidneys of male mice accumulated more OTA than did the testes at all doses. An increase in OTA administered over the low dose of $3.5 \mu \mathrm{g} / \mathrm{kg}$ b.w. by 300-fold led to an approximately 100 -fold increase in OTA content in kidney. In the testis, OTA only accumulated when the dose was higher than $35 \mu \mathrm{g} / \mathrm{kg}$ b.w. (corresponding to $0.2 \mathrm{ppm}$ in the feed). Following treatment of mice by a 15-fold higher amount of OTA $(1,056 \mu \mathrm{g} / \mathrm{kg}$ b.w. vs. $70 \mu \mathrm{g} / \mathrm{kg}$ b.w.), the OTA in testis was 30 -fold higher.

Table 1. OTA content in kidney and testis of BALB/c treated with increasing concentrations of OTA by oral gavage

\begin{tabular}{ccc}
\hline $\begin{array}{c}\text { OTA administered by gavage } \\
\boldsymbol{\mu g} / \mathbf{k g} \mathbf{b . w .}\end{array}$ & $\begin{array}{c}\text { OTA content in testis* } \\
\mathbf{n g} / \mathbf{g}\end{array}$ & $\begin{array}{c}\text { OTA content in kidney* } \\
\mathbf{n g} / \mathbf{g}\end{array}$ \\
\hline 0 & nd** & nd \\
3.5 & nd & $3.5 \pm 1.4^{*}$ \\
7 & nd & $8.2 \pm 0.7$ \\
35 & nd & $110 \pm 2.5$ \\
70 & $1.6 \pm 0.2$ & $123 \pm 2$ \\
289 & $3 \pm 0.1$ & $110 \pm 27$ \\
578 & $9.6 \pm 1.5$ & $210 \pm 30$ \\
1056 & $50 \pm 15$ & $330 \pm 60$ \\
\hline
\end{tabular}

* average of three animals; ** not detectable (below limit of detection) 


\subsubsection{Identification of OTA Metabolites in Tissues}

OTA and its metabolites were extracted from urine, liver, kidney and testis of mice fed increasing amount of OTA for 4 weeks. The metabolites were separated by gradient elution. An example of separation is given in Figure 4. Most of the OTA metabolites have been identified by LC MS/MS [27]).

Figure 4. OTA metabolites detected in urine (A) and liver (B) of OTA treated males OTHQ (quinone OTA); GSH conjugated to glutathione; NAC conjugated to $N$-acetylcystein, DC OTHQ decarboxylated OTHQ; OP OA open ring OTA; OTB dechlorinated OTA; OTC ethylated OTA.

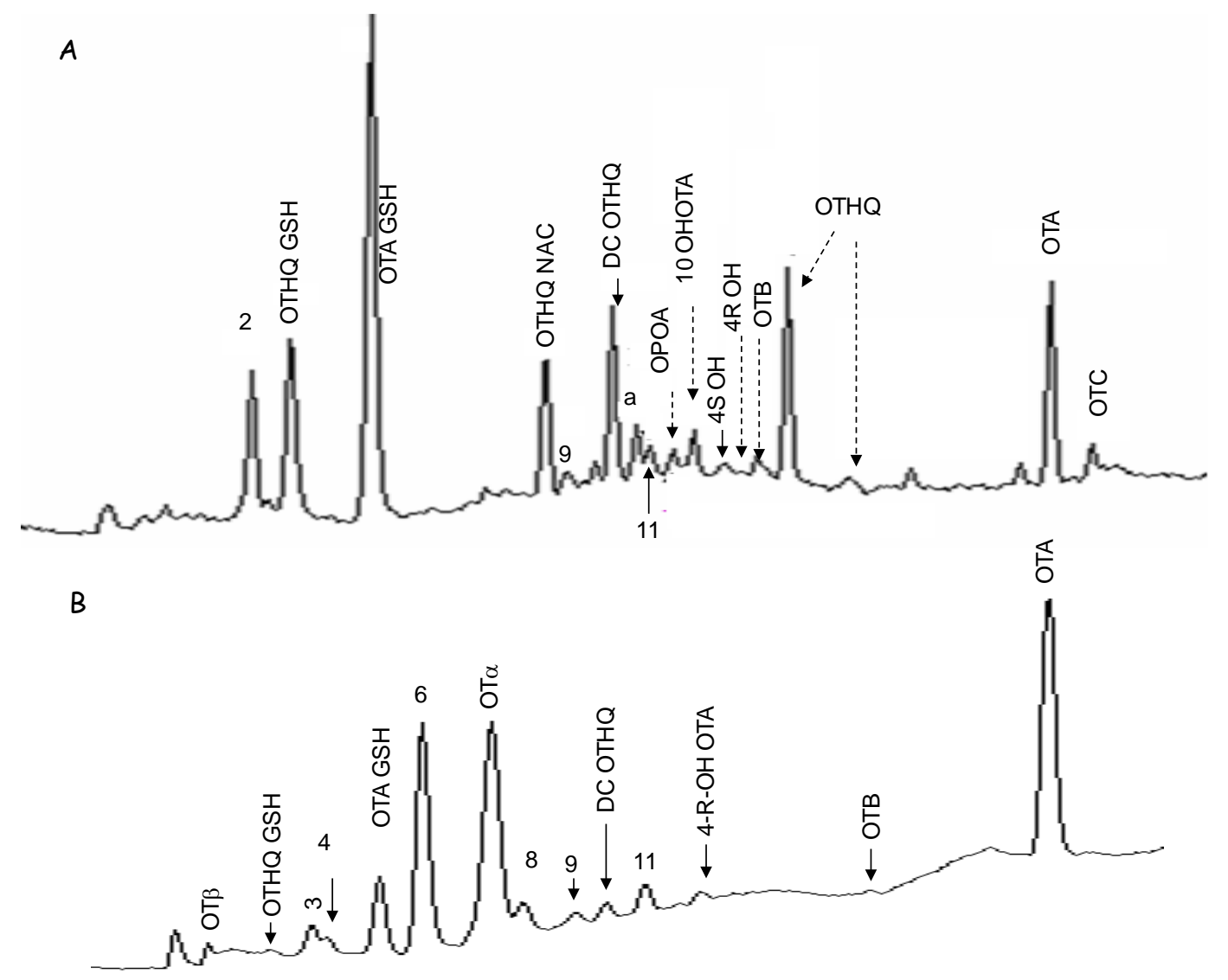

In male kidney and in testis, twelve metabolites were formed in both organs: OT $\beta$; metabolite "2"; OTHQ-GSH; OTA-GSH; OT $\alpha$; OTHQ-NAC; DC-OTHQ; 4R-OH-OTA; OTHQ; OTC. Two metabolites were observed in kidney but not in testis: 4S-OH-OTA and metabolite "9". Some OTA metabolites were formed in liver but not in kidney and testis, such metabolites 3, 4, 6, 11 and OTB. The OTHQ metabolites (OTHQ; DC-OTHQ, OTHQ-NAC) are not detected in liver.

\subsection{Effect of Transplacental OTA Contamination on Male Mice Pup}

\subsubsection{Transplacental Toxicity}

No overt toxicity of OTA was detected in either dams or litters. An average of 7-8 pups were delivered to both control and OTA-treated mothers, with an average birth weight of $1.5 \mathrm{~g} / \mathrm{pup}$ and 
$1.4 \mathrm{~g} /$ pup, respectively. Survival to weaning was also equivalent (50/57 in controls vs. 48/56 in OTA-treated) as was weight at 1 month of age (21.7 g/male and $18.4 \mathrm{~g} /$ female in controls vs. $21.4 \mathrm{~g} / \mathrm{male}$ and $18.2 \mathrm{~g} /$ female in OTA-treated) (Figure 5).

Figure 5. Comparison of litter size, survival and weight of mice treated or not by OTA (CON = control animal; OTA = ochratoxin A treated animal).
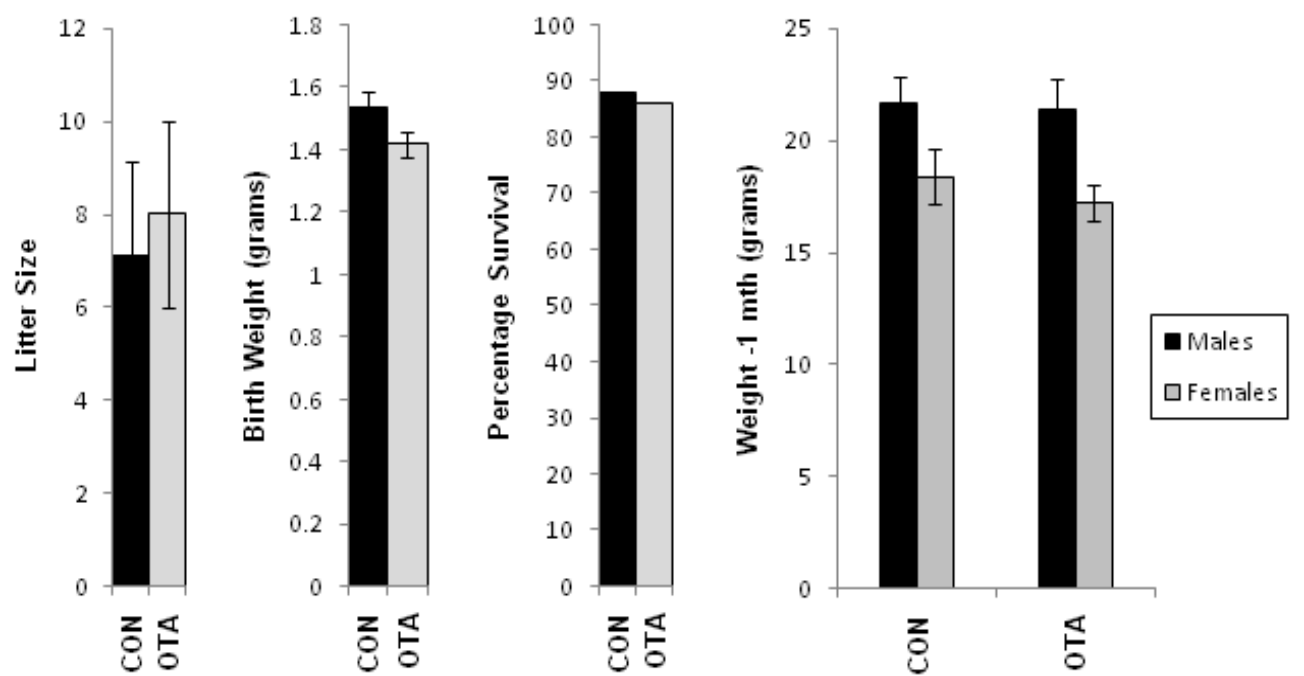

z형

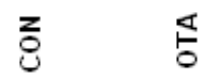

3.2.2. DNA Adduct Analysis in Kidney and Testis of Male Mice Pup

DNA adducts were analyzed in kidney and testis from newborn male littermates exposed to OTA at 17 days gestation and from 8 male mice aged 1 month. Three male mice were born from one mother and five from another. No adducts were detected in the testis and kidney of untreated mice. Several adducts were observed as well in kidney as in testis of pups born from OTA-treated mothers. A representative example of DNA adduct pattern in testis is shown in Figure 6.

Figure 6. DNA adduct pattern of testis of one-month old mice. (A) litter from untreated mother mice; (B, C, D) litter from OTA-treated mother (arrow points C-C8dG OTA); (B \& C) correspond to two animals from Mother Number 2; (D) corresponds to one animal from Mother Number 1.
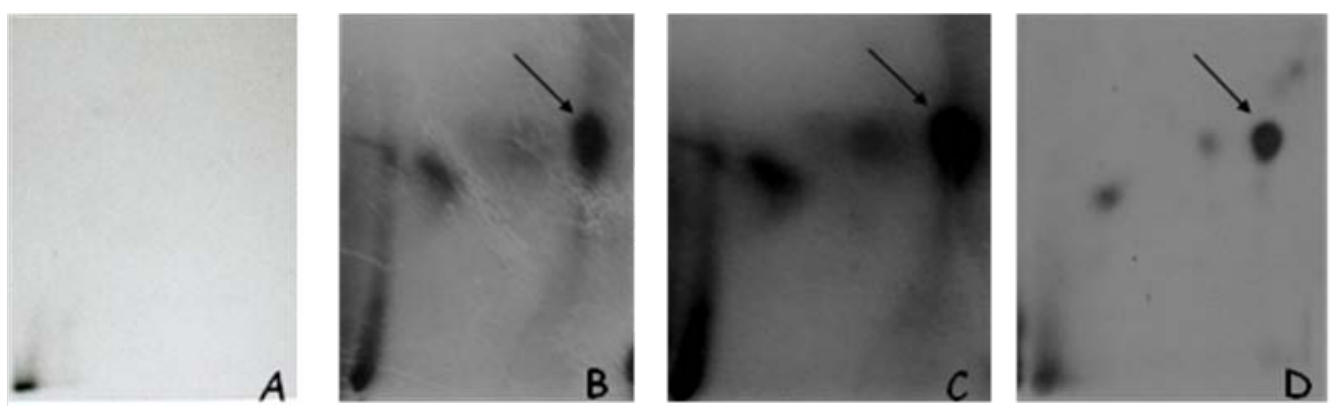

Mainly, three adducts were formed in kidney and testis of the male pups. These adducts correspond to adducts numbered "2", “6”, “1” observed in adult mice (see Figure 1 for numbering). The intensity of the adducts differed according to the tissue and age of the animals. In newborn male mice adduct 
"6" is formed neither in kidney nor in testis. This suggest that adduct "6" likely results from OTA contamination via suckling, and explains why the DNA adduct amounts are higher in one month pups than in newborns. In order to confirm the structure of the adduct 1, comigration of testis DNA was performed with either kidney DNA or the C-C8 dGMP-OTA DNA standard. After D1 migration, the spot corresponding to C-C8dG OTA was cut out in each sample (Figure 7A). These spots were transferred onto a new plate and eluted in two dimensions. The main spot in kidney co-migrated with the main spot in testis. This spot co-migrated with C-C8 dGMP-OTA (Figure 7B). The structure of this adduct is given Figure 8 .

Figure 7. Comigration of mouse testis DNA with kidney DNA or C-C8 dG OTA standard (A) D1 migration; The upper part is cut out and transferred onto new plates as described in Mantle et al., 2010 [30]; (B) C-C8dG OTA spot; Testis spot; comigration 1/2 C-C8dGOTA + 1/2 Testis; comigration $1 / 2$ kidney $+1 / 2$ testis.
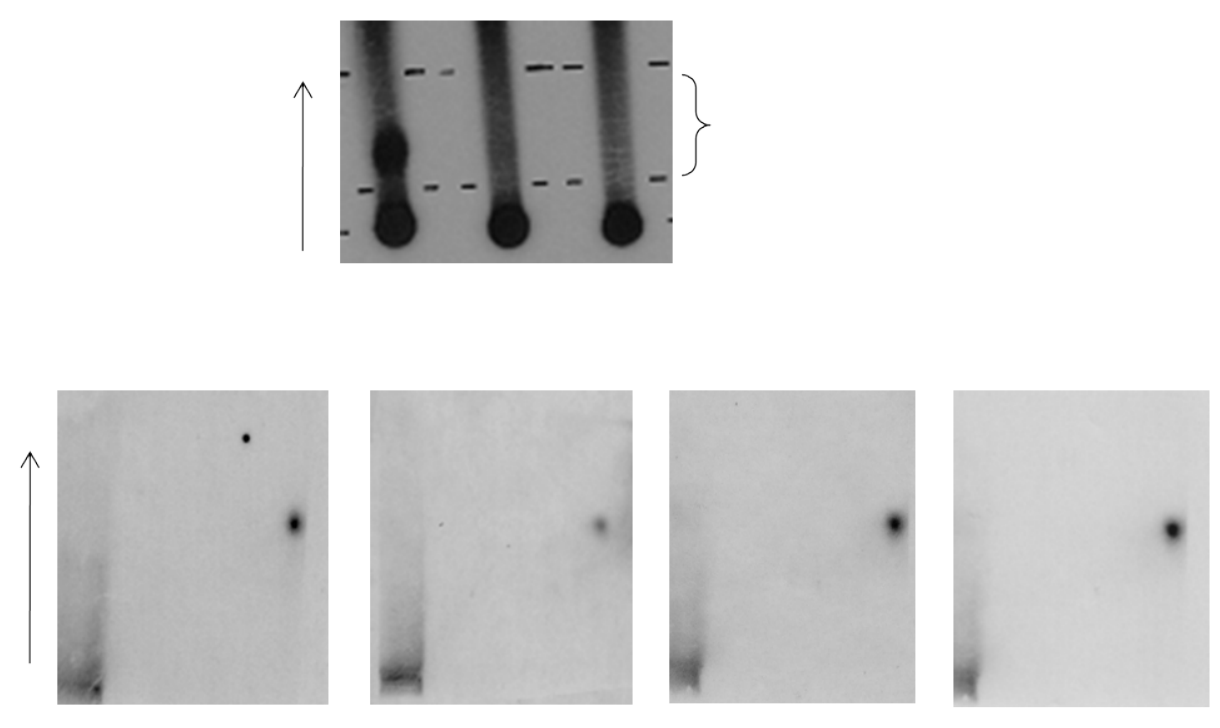

The mean C-C8dGMP-adduct level, measured on the organs in newborns, was $5.2 \pm 0.1$ and $4.2 \pm 0.2$ nucleotides per $10^{9}$ nucleotides in testis and kidney, respectively. The quantity of this latter adduct for each one-month old animal is shown in Table 2.

Figure 8. Structure of C-C8 dG-OTA.

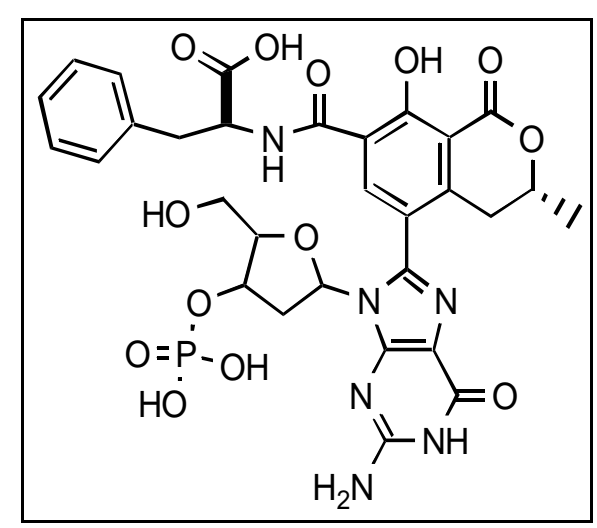


Table 2. Amount of C-C8dG OTA in kidney and in testis of one-month old mice contaminated with OTA via the transplacental route.

\begin{tabular}{llll}
\hline & $\begin{array}{l}\text { Animal } \\
\text { Numbering }\end{array}$ & $\begin{array}{l}\text { C-C8dG OTA } \\
\text { in Testis }\end{array}$ & $\begin{array}{l}\text { C-C8dG OTA in } \\
\text { Kidney }\end{array}$ \\
\hline Mother 1 & 1 & $5.5 \pm 0.3$ & $4.8 \pm 0.2$ \\
& 2 & $5.7 \pm 0.3$ & $5.1 \pm 0.3$ \\
Mother 2 & 3 & $5.1 \pm 0.3$ & $4.7 \pm 0.2$ \\
& 4 & $7.3 \pm 0.5$ & $6.3 \pm 0.2$ \\
& 5 & $8.3 \pm 0.5$ & $6.5 \pm 0.4$ \\
& 6 & $7.7 \pm 0.3$ & $6.9 \pm 0.5$ \\
& 7 & $7 \pm 0.6$ & $6.6 \pm 0.3$ \\
\hline
\end{tabular}

The amount of C-C8dG OTA was significantly higher in testis compared to kidney. Pups from the same mother have a similar amount of C-C8 dG OTA.

\section{Discussion}

Our results from gavage-feeding experiments are similar to those described previously $[15,16]$. Unlike Gharbi et al., [17], who administered $289 \mu \mathrm{g} / \mathrm{kg}$ b.w. OTA every $48 \mathrm{hrs}$ for a period of 8 weeks (i.e., chronic administration), we showed that OTA induced adducts in testicular DNA after a single (acute) exposure using OTA doses that were 10-fold lower ( $<1 \mathrm{ppm}$ in food). The number of individuals adducts increased with the dose. Daily intake of low amounts of OTA in feed induced the formation of the main adduct.

To our knowledge, this is the first study to demonstrate that maternal exposure to OTA causes DNA adducts in the testis of newborn mice. These adducts are chromatographically similar to adducts in kidney and in testicular DNA that were produced by feeding OTA to adult mice by gavage. The main adduct observed in the testis comigrated with the C-C8dGMP OTA adduct which was also the main adduct in the kidney and has been recently identified by MS/MS (Mantle et al., 2010 [30]). This adduct is dechlorinated and thus could be formed only after OTA biotransformation [21,22,27,29,30]. The susceptibility of male rats to kidney cancer after OTA exposure is highly dependent on enzymes regulated by sexual hormones such CYP 2C [28] but also on enzymes involved in oxidative pathways [21] such cyclooxygenases [32-34] and glutathione conjugation [27,35]. Interestingly, Verma \& Chakraborty [36] observed a decrease of catalase, SOD, glutathione peroxidase activities and of the amount of glutathione in testis of mice exposed to OTA. In testis and in kidney of mice fed OTA, we detected OTHQ formed via the peroxidase pathway [21]. In testis and kidney, several quinone metabolites were formed (OTHQ = ochratoxine hydroquinone; DC-OTHQ = decarboxylated OTHQ; OTHQ-GSH = conjugated to glutathione; OTHQ-NAC = conjugated to N-acetylcystein). These metabolites were not found in liver. This indicates that quinone formation arose in tissues having cylooxygenase, CYP 2C and glutathione conjugation pathways as it is the case mainly in kidney and testis. Interestingly, CYP 2C is induced by sex hormones [38] and is regulated by CYP 3A4 [38] which is abundantly expressed in the human liver, intestine and kidney. The CYP 3A5*1 allele was more prevalent in patients suffering from Balkan endemic nephropathy (BEN), for which OTA is a plausible 
etiologic agent, with a frequency of $9.4 \%$ versus $5.4 \%$ in controls, and was associated with a higher risk for BEN (Odds Ratio = 2.41) [39].

Adduct levels appeared to increase over time, as levels in month-old mice were greater than in newborns. This could be explained by the high affinity of OTA for proteins, accumulated in tissue of newborn and released for a long time after exposure. In addition, OTA is excreted in milk and thus exposure of the newborn to OTA continues after birth (for a review see [2]).

The C-C8dGMP OTA adduct is the same adduct consistently observed in kidney tumors from patients with BEN in the Balkans and in other European countries [40-42]. In this regard, it is noteworthy that a recent epidemiologic study of BEN in the Vratza District, Bulgaria (where BEN was first characterized), found that cases of BEN in adults were associated with the presence of BEN in the mother, but not in the father [43]. These findings suggest that exposure to OTA in utero may play an etiologic role in BEN.

Our finding that OTA caused DNA adducts in testes of newborns is consistent with the hypothesis of a possible role for exposure to OTA in testicular cancer [10]. Little is known about the etiology of testicular cancer, but its peculiar age-incidence curve, showing a peak in adolescence, and the identification of carcinoma in situ of the testis in pre-pubertal testes, suggests that the causes of testicular cancer occur in utero or peri-natally $[44,45]$. The only established cause of testicular cancer is cryptorchidism (failure of the testes to descend into the scrotum). However, it is widely believed that it is not cryptorchidism per se that causes testicular cancer, but rather, that cryptorchidism and testicular cancer share a common cause. A role for endocrine disruptors has long been suggested in testicular cancer, male infertility and in cryptorchidism (i.e., the "testicular dysgenesis syndrome") but the identity of the agent(s) responsible for these epidemics is a mystery [46]. It is intriguing in this regard that OTA is known to cause inhibition of testosterone secretion [47], poor semen quality [48-50] and cryptorchidism. Thus, Wangikar et al., [51] found a significantly increased incidence of cryptorchid testes (2/12 OTA-treated pups vs. 0/43 controls) in Wistar rats given $0.75 \mathrm{mg}$ OTA/kg on days $6-15$ of gestation ( $\mathrm{P}=0.006)$. Similarly, Patil et al., [52] studied the effects of a single dose of OTAat $2.75 \mathrm{mg} / \mathrm{kg}$ body weight on maternal and fetal toxicity of pregnant Wistar rats. They observed a high incidence of gross abnormalities to fetuses from OTA exposure on gestation day (GD) 6 and 7 (13 and 18\%, respectively). Five instances of cryptorchid testes (of 92 foetuses examined) were observed on GD 6-10 and GD 13.

The recent observation that Dmrt-1 gene expression is markedly reduced in conceptuses of male mice from dams treated with OTA is particularly noteworthy [11]. Although Dmrt-1 is essential for the embryonic development of the testis in humans, Dmrt-1 is involved in the postnatal development of the testis in rodents [53]. This may explain the development of testis cancer in older Fischer rats chronically exposed to OTA via the diet [13].

\section{Conclusions}

We demonstrated that intrauterine exposure to OTA produces DNA adducts in the testes of newborn mice and that these adducts are similar to the DNA adducts that are observed in the kidney and testis of adult mice that are exposed to OTA via the diet. These data add additional support to the hypothesis that OTA may play a role in the etiology of testicular cancer [10]. 


\section{Acknowledgements}

This research program was partly funded by EU project "Mechanisms of Ochratoxin A Induced Carcinogenicity as a Basis for an Improved Risk Assessment” Ochratoxin A- Risk Assessment: Contract QLK1-CT-2001-01614 (A.P-L.) and by “Région Midi-Pyrénées” Nº1002778; 01009089; 03011987. (A.P-L). The authors thank also French ministry (Eiffel program), AUF (association universitaire pour la francophonie); “Ligue Nationale Française contre la cancer' and “association pour la recherché contre le cancer ARC' for financial support to M.T. Additional grant support was provided by the Lance Armstrong Foundation (G.G.S.), by a pilot grant from the Comprehensive Cancer Center of Wake Forest University (G.G.S.), and a training grant T32-ES07331 from the National Institute of Environmental Health Sciences (for J.J.-G.). Virginie Faucet-Marquis and Jian Dia are acknowledged for their help (respectively for improvement of DNA adduct analysis and synthesis of the C-C8 dG OTA standard).

\section{References}

1. O’Brien, E.; Dietrich, D.R. Ochratoxin A: The continuing enigma. Critical Reviews. Toxicology 2005, 35, 33-60.

2. Pfohl-Leszkowicz, A.; Manderville, R.A. Ochratoxin A: An overview on toxicity and carcinogenicity in animals and humans. Mol. Nutr. Food Res. 2007, 51, 61-99.

3. Reddy, L.; Boohla, K. Ochratoxins-Food Contaminants: Impact on Health. Toxins 2010, 2, 771-779.

4. Krogh, P. Epidemiology of mycotoxic porcine nephropathy. Nord. Vet. Med. 1976, 28, 452-458.

5. Stoev, S.D. The role of ochratoxin A as a possible cause of Balkan endemic nephropathy and its risk evaluation. Vet. Human Toxicol. 1998, 40, 352-360.

6. Chernozemsky, I.N.; Stoyanov, I.S.; Petkova-Bocharova, T.K.; Nicolov, I.G.; Draganov, I.V.; Stoichev, I.I.; Tanchev, Y.; Naidenov, D.; Kalcheva, N.D. Geographic correlation between the occurrence of endemic nephropathy and urinary tract tumours in Vratza district, Bulgaria. Int. J. Cancer 1977, 19, 1-11.

7. Pfohl-Leszkowicz, A.; Petkova-Bocharova, T.; Chernozemsky, I.N.; Castegnaro, M. Balkan endemic nephropathy and the associated urinary tract tumours: Review on etiological causes, potential role of mycotoxins. Food Add. Contam. 2002, 19, 282-302.

8. Castegnaro, M.; Chernozemsky, I.; Bartsch, H. Endemic nephropathy and urinary tract tumours in the Balkans. Cancer Res. 1987, 47, 3608-3609.

9. Huyghe, E.; Plante, P.; Thonneau, P.F. Testicular cancer variations in time and space in Europe. Eur. Urol. 2007, 51, 621-628.

10. Schwartz, G.G. Hypothesis: Does ochratoxin A cause testicular cancer? Cancer Causes Control 2002, 13, 91-100.

11. Ueta, E.; Kodama, M.; Sumino, Y.; Kurome, M.; Ohta, K.; Katagiri, R.Y.; Naruse, I. Gender-dependent differences in the incidence of ochratoxin A-induced neural tube defects in the Pdn/Pdn mouse. Congenit. Anom. (Kyoto) 2010, 50, 29-39. 
12. Raymond, C.S.; Murphy, M.W.; O’Sullivan, M.G.; Bardwell, V.J.; Zarkower, D. Dmrt1, a gene related to worm and fly sexual regulators, is required for mammalian testis differentiation. Genes Develop. 2000, 14, 2587-2595.

13. Mantle, P.G.; Nolan, C.C. Pathological Outcomes in Kidney and Brain in Male Fischer Rats Given Dietary Ochratoxin A, Commencing at One Year of Age. Toxins 2010, 2, 1100-1110.

14. Mantle, P.G.; Kulinskaya, E.; Nestler, S. Renal tumourigenesis in male rats in response to chronic dietary ochratoxin A. Food Addit. Contam. A 2005, 22, 58-64.

15. Pfohl-Leszkowicz, A.; Grosse, Y.; Kane, A.; Gharbi, A.; Baudrimont, I.; Obrecht, S.; Creppy, E.E.; Dirheimer, G. Is the oxidative pathway implicated in the genotoxicity of ochratoxin A? In Human Ochratoxicosis and Related Pathologies; Libbey, J., Ed.; Colloque INSERM: London, UK, 1993.

16. Gharbi, A.; Trillon, O.; Betbeder, A.M.; Counord, J.; Gauret, M.F.; Pfohl-Leszkowicz, A.; Dirheimer, G.; Creppy, E.E. Some effects of ochratoxin A, a mycotoxin contaminating feeds and food, on rat testis. Toxicology 1993, 83, 9-18.

17. Petkova-Bocharova, T.; Stoichev, I.I.; Chernozemsky, I.N.; Castegnaro, M.; Pfohl-Leszkowicz, A. Formation of DNA adducts in tissues of mouse progeny through transplacental contamination and/or lactation after administration of a single dose of ochratoxin A to the pregnant mother. Environ. Mol. Mutagen. 1998, 32, 155-162.

18. Petkova-Bocharova, T.; Pfohl-Leszkowicz, A.; Hadjiolov, D.; Spirov, K. Investigation on the genotoxicity of Ochratoxin A by measurement of DNA-adducts in different organs of Syrian hamsters. Rev. Med. Vet. 1998, 149, 658.

19. Satoh, M. Histogenesis and organogenesis of the gonad in human embryos. J. Anat. 1991, 177, 85-107.

20. Smith's General Urology, 16th ed.; Tanagho, E.A., McAninich, J.W., Eds.; McGraw-Hill Companies, Inc: New York, NY, USA, 2004.

21. Manderville, R.A.; Pfohl-Leszkowicz, A. Bioactivation and DNA adduction as a rationale for Ochratoxin A carcinogenesis. World Mycotoxin J. 2008, 1, 357-367.

22. Faucet, V.; Pfohl-Leszkowicz, A.; Dai, J.; Castegnaro, M.; Manderville, R.A. Evidence for covalent DNA adduction by Ochratoxin A following chronic exposure to rat and subacute exposure to pig. Chem. Res. Toxicol. 2004, 17, 1289-1296.

23. Gillman, I.G.; Clark, T.N.; Manderville, R.A. Oxidation of ochratoxin A by an FE-Porphyrin system Model for enzymatic activation and DNA cleavage. Chem. Res. Toxicol. 1999, 12, 1066-1076.

24. Molinié, A.; Faucet, V.; Castegnaro, M.; Pfohl-leszkowicz, A. Analysis of some breakfast cereals collected on the French market for their content in ochratoxin A, citrinin and fumonisin B1. Development of a new method for simultaneous extraction of ochratoxin A and citrinin. Food Chem. 2005, 92, 391-400

25. Nguyen, M.T.; Toslovanu, M.; Tran, T.L.; Pfohl-Leszkowicz, A. Occurrence of aflatoxin B1, citrinin and ochratoxin a in rice in five provinces of central region in Vietnam. Food Chem. 2007, 105, 42-47.

26. Petkova-Bocharova, T.; Castegnaro, M.; Pfohl-Leszkowicz, A.; Garren, L.; Grosso, F.; Nikolov, I.; Vrabcheva, T.; Dragacci, S.; Chernozemsky, I. Analysis of ochratoxin A in serum and urine of 
inhabitants from an area with Balkan Endemic Nephropathy: A one month follow up study. Facta Universitatis series: Med. Biol. 2003, 10, 62-68.

27. Faucet-Marquis, V.; Pont, F., Størmer, F.; Rizk, T.; Castegnaro, M.; Pfohl-Leszkowicz, A. Evidence of a new dechlorinated OTA derivative formed in opossum kidney cell cultures after pre-treatment by modulators of glutathione pathways. Correlation with DNA adducts formation. Mol. Nutr. Food Res. 2006, 50, 531-542.

28. Frenette, C.; Paugh, R.; Tozlovanu, M.; Juzio, M.; Pfohl-Leszkowicz, A.; Manderville, R. Structure-activity relationships for the fluorescence of ochratoxin A: Insight for detection of ochratoxin A metabolites. Anal. Chim. Acta 2008, 617, 153-161.

29. Pfohl-Leszkowicz, A.; Castegnaro, M. Further arguments in favour of direct covalent binding of Ochratoxin A (OTA) after metabolic biotransformation. Food Addit. Contam. 2005, 22, 75-87.

30. Mantle, P.; Faucet-Marquis, V.; Manderville, R.; Sciqualli, B.; Pfohl-Leszkowicz, A. Structures of covalent adducts between DNA and ochratoxin A: A new factor in debate about genotoxicity and human risk assessment. Chem. Res. Toxicol. 2010, 23, 89-98.

31. Pfohl-Leszkowicz, A.; Pinelli, E.; Bartsch, H.; Mohr, U.; Castegnaro, M. Sex and Strain differences in ochratoxin A metabolism and DNA adduction in two strains of rats. Mol. Carcino. 1998, 23, 76-83

32. Pinelli, E.; El Adlouni, C.; Pipy, B.; Quartulli, F.; Pfohl-Leszkowicz, A. Respective implication of cyclooxygenase and lipoxygenase in ochratoxin A genotoxicity on human epithelial lung cells. Environ. Toxicol. Pharmacol. 1999, 7, 95-107

33. El Adlouni, C.; Pinelli, E.; Azémar, B.; Zaoui, D.; Beaune, P.; Pfohl-Leszkowicz, A. Role of CYP 2C and microsomal glutathione-S-transferase in modulating susceptibility to ochratoxin A genotoxicity. Environ. Mol. Mutagen. 2000, 35, 123-131

34. Petkova-Bocharova, T.; El Adlouni, C.; Faucet, V.; Pfohl-Leszkowicz, A.; Mantle, P. Analysis for DNA adducts, ochratoxin A content and enzymes expression in kidneys of pigs exposed to mild experimental chronic ochratoxicosis. Facta universitatis, series: Med. Biol. 2003, 10, 111-115.

35. Pfohl-Leszkowicz, A.; Bartsch, H.; Azémar, B.; Mohr, U.; Estève, J.; Castegnaro, M. MESNA protects rats against nephrotoxicity but not carcinogenicity induced by ochratoxin A, implicating two separate pathways. Facta universitatis, series: Med. Biol. 2002, 9, 57-63.

36. Verma R.; Chakraborty, D. Emblica officinalis aqueous extract ameliorates ochratoxin-induced lipid peroxidation in the testis of mice. Acta Poliniae Pharm. Drug Res. 2008, 65, 187-194.

37. Kamataki, T.; Maeda, K.; Yamazoe, Y.; Nagai, T.; Kato, R. Sex difference of cytochrome P-450 in the rat: Purification, characterization, and quantitation of constitutive forms of cytochrome-P450 from liver microsomes of male and female rats. Arch. Biochem. Biophys. 1983, 225, 758-777.

38. Gustafsson, J.A.; Mode, A.; Norstedt, G.; Skett, P. Sex steroid induced changes in hepatic enzymes. Annu. Rev. Physiol. 1983, 45, 51-60.

39. Atanasova, S.Y.; Von Ahsen, N.; Toncheva, D.; Dimitrov, T.G.; Oellerich, M.; Armstrong, V.W. Genetic polymorphisms of cytochrome P450 among patients with Balkan endemic nephropathy (BEN). Clin. Biochem. 2005, 38, 223-228

40. Pfohl-Leszkowicz, A.; Grosse, Y.; Castegnaro, M.; Petkova-Bocharova, T.; Nicolov, I.G.; Chernozemsky, I.N.; Bartsch, H.; Betbeder, A.M.; Creppy, E.E.; Dirheimer, G. Ochratoxin A 
related DNA adducts in urinary tract tumours of Bulgarian subjects. IARC Sci. Publ. 1993, 124, 141-148.

41. Pfohl-Leszkowicz, A.; Tozlovanu, M.; Manderville, R.; Peraica, M.; Castegnaro, M.; Stefanovic, V. New molecular and field evidences for the implication of mycotoxins but not aristolochic acid in Human Nephropathy and Urinary tract tumor. Mol. Nutr. Food Res. 2007, 51, 131-146.

42. Pfohl-Leszkowicz, A. Ochratoxin A and aristolochic acid in the Nephropathies and Associated Urothelial Tract Tumours development. Arh. Hig. Rada. Toksikol. 2009, 60, 465-483.

43. Dimitrov, P.; Tsolova, S.; Georgieva, R.; Bozhilova, D.; Simeonov, V.; Bonev, A.; Karmaus, W. Clinical markers in adult offspring of families with and without Balkan Endemic Nephropathy. Kidney Int. 2006, 69, 723-729.

44. Møller, H. Clues to the aetiology of testicular germ cell tumours from descriptive epidemiology. Eur. Eurol. 1993, 23, 8-15.

45. Rajpert-De Meyts, E. Developmental model for the pathogenesis of testicular carcinoma in situ: Genetic and environmental aspects. Human Reprod. Update 2006, 12, 303-323

46. Bay, K.; Asklund, C.; Skakkebaek, N.E.; Andersson, A.-M. Testicular dysgenesis syndrome: Possible role of endocrine disrupters. Best Pract. Res. Clin. Endocrinol. Metab. 2006, 21, 77-90.

47. Fenske, M.; Fink-Gremmels, J. Effects of fungal metabolites on testosterone secretion in vitro. Arch. Toxicol. 1990, 64, 72-75

48. Bose, S.; Sinha, S.P. Modulation of ochratoxin-produced genotoxicity in mice by vitamin C. Food Chem. Toxicol. 1994, 32, 533-537.

49. Solti, L.; Pécsi, T.; Barna-Vetro, I.; Szasz, F.; Szabo, F. Analysis of serum and seminal plasma after feeding ochratoxin A with breeding boars. Anim. Reprod. Sci. 1999, 56, 125-132.

50. Biro, K.; Barna-Vetro, I.; Pesci,T.; Szabo, E.; Winkler, G; Fink-Gremmels, J.; Solti L. Evaluation of spermatological parameters in ochratoxin A-challenged boars. Theriogenology 2003, 60, 199-207.

51. Wangikar, P.T.; Dwivedi, P.; Sinha, N. Effect in rats of simultaneous prenatal exposure to Ochratoxin A and Aflatoxin B1/I. Maternal toxicity and fetal malformations. Birth Defects Res. B 2004, 71, 343-351.

52. Patil, R.D.; Dwivedi, P.; Sharma, A.K. Critical period and minimum single oral dose of ochratoxin A for inducing developmental toxicity in pregnant Wistar rats. Reprod. Toxicol. 2006, 22, 697-687.

53. Lei, N.; Karpova, T.; Hornbaker, K.I.; Rice, D.A.; Heckert, L.L. Distinct transcriptional mechanisms direct expression of the rat Dmrt1 Promoter in Sertoli cells and germ cells of transgenic mice. Biol. Reproduct. 2009, 81, 118-125.

(C) 2010 by the authors; licensee MDPI, Basel, Switzerland. This article is an Open Access article distributed under the terms and conditions of the Creative Commons Attribution license (http://creativecommons.org/licenses/by/3.0/). 